\begin{tabular}{|c|l|}
\hline Title & $\begin{array}{l}\text { Detection of thyroid hormone receptors in the olfactory system and brain of wild masu sal mon, Oncorhynchus masou } \\
\text { (Brevoort), during smolting by in vitro autoradiography }\end{array}$ \\
\hline Author(s) & Kudo, H.; T suneyoshi, Y.; Nagæe, M.; A dachi, S.; Y amauchi, K.; Ueda, H.; Kawamura, H. \\
\hline Citation & $\begin{array}{l}\text { A quaculture and Fisheries Management, 25(Supplement 2), 171-182 } \\
\text { https://doi.org/10.1111/are.1994.25.s2.171 }\end{array}$ \\
\hline Issue Date & 1994 \\
\hline Doc URL & http://hdl.handle.net/2115/39718 \\
\hline Rights & The definitive version was published by Blackwell Publishing. \\
\hline Type & article (author version) \\
\hline File Information & AFM1994_Kudo.pdf \\
\hline
\end{tabular}

Instructions for use 


\section{Detection of thyroid hormone receptors in the olfactory system and brain of wild masu salmon, Oncorhynchus masou (Brevoort), during smolting by in vitro autoradiography}

H. Kudo, Y. Tsuneyoshi, M. Nagae, S. Adachi \& K. Yamauchi

Department of Biology, Faculty of Fisheries, Hokkaido University, Hakodate, Japan

H. Ueda

Toya Lake Station for Environmental Biology, Faculty of Fisheries, Hokkaido University, Abuta, Japan

H. Kawamura

Makkari Branch, Hokkaido Fish Hatchery, Abuta, Japan

Running title: T3 receptors in masu salmon olfactory system and brain.

Text: 13

Figure legends: 1

Figures: 7

Correspondence: Dr. K. Yamauchi, Department of Biology, Faculty of Fisheries, Hokkaido University, 3-1-1 Minato-cho, Hakodate, Hokkaido 041, Japan

(Present correspondence: H. Kudo, Faculty of Fisheries, Hokkaido University, 3-1-1 Minato-cho, Hakodate,

Hokkaido 041-8611, Japan. E-mail: hidea-k@fish.hokudai.ac.jp) 


\begin{abstract}
.
Thyroid hormone regulates a number of physiological functions during smolting in salmonids. However, the target sites and roles of thyroid hormone in the central nervous system (CNS) are not known in detail. We detected thyroid hormone-specific binding sites (i.e. thyroid hormone receptors) in the olfactory epithelium and the brain (the olfactory bulb, the telencephalon, the mid-brain and the cerebellum) of wild masu salmon, Oncorhynchus masou (Brevoort), during smolting by means of in vitro autoradiography with frozen sections. A saturation experiment with the brain indicated the presence of a single class of binding sites of high affinity. $\mathrm{T}_{3}$-specific binding was detected in the olfactory epithelium and in all regions of the brain except the olfactory bulb. The $\mathrm{T}_{3}$-specific binding value in the olfactory epithelium was higher than in all other regions of the brain. This binding value in the olfactory epithelium increased at the full-smolt stage. The presence of thyroid hormone receptors in various regions of the CNS suggests that thyroid hormone plays an important role in the functional change in the brain and the olfactory epithelium during smolting.
\end{abstract}




\section{Introduction}

Smolting (parr-smolt transformation) in salmonids is a complex phenomenon on comprising various morphological, physiological and behavioural changes that are under endocrine control (Hoar 1976). These events appear to be regulated by various hormones such as thyroid hormone, growth hormone and cortisol (Hoar1988; Young; Björnsson; Prunet, Lin \& Bern 1989). Thyroid hormone is one of the most important hormones during smolting. It is suggested that thyroid-hormones are related to body silvering (Ura, Hara \& Yamauchi 1994), seawater adaptation (Folmar \& Dickhoff 1980), and downstream migration behaviour (Hoar1976). However, the mechanisms of thyroid hormone action remain largely unexplored. In particular, little is known about the relationship between thyroid hormone and downstream migration.

Serum levels of thyroid hormone gradually increase as smolting progresses and peak at the full-smolt stage, declining thereafter (Dickhoff, Folmar, Mighell \& Mahnken 1982; Yamauchi, Koide, Adachi \& Nagahama 1984). These studies suggest that the peak in thyroid hormone production affects the behavioural change in downstream migration by controlling the central nervous system (CNS). The existence of a thyroid hormone receptor was indicated in the brain of rainbow trout, Oncorhynchus mykiss (Walbaum) (Bres \& Eales1988). Specific binding of triiodothyronine $\left(\mathrm{T}_{3}\right)$ in the nuclei of the brain and the olfactory epithelium increased during thyroid-stimulating hormone-induced smolting (Scholz, White, Muzi \& Smith 1985). In these studies, however, homogenates of whole-brain tissues were used. Therefore, the localization of the thyroid hormone receptor in various portions of the brain remains unclear. In the present study, We searched for thyroid hormone-specific binding sites (i.e. thyroid hormone receptors) in the olfactory epithelium and the brain (the olfactory bulb, the telencephalon, the mid-brain and the cerebellum)of wild masu salmon during smolting by means of in vitro autoradiography with frozen sections.

\section{Materials and methods}

Fish

Yearling wild masu salmon, Oncorhynchus masou (Brevoort), were collected monthly from the Shakotan River, Hokkaido, Japan by either a cast net or an electric shocker (Model12 Electrofisher, Smith-Root, Washington, USA) from November 1991 to May 1992 and from 
November 1992 to May 1993. Fork length (FL) and body weight (BW) gradually increased from November 1991 to April 1992 (FL, 10.2-11.8 cm; BW, 10.4-11.8 g), and reached maximum values in May (FL, $14.1 \mathrm{~cm}$; BW, 30.7 g; Fig. 1A). Parr marks were evident without any body silvering in the parr (November) samples and were obscured in the pre-smolt (April) samples. In the full-smolt (May) samples, parr marks were completely absent, while the fins were clear with intense black pigment at the outer extremities of the dorsal and caudal fin lobes. Water temperature of the river reached a minimum value of $0^{\circ} \mathrm{C}$ and the river surface was covered with ice in February 1992. The water temperature of the river increased from March to May 1992 (5.0-10.8 ${ }^{\circ}$; Fig. 1B).

\section{Blood and tissue samples}

Fish were anaesthetized with ethyl p-aminobenzoate and blood samples were collected from their caudal vessels. Blood was allowed to clot (overnight, $4^{\circ} \mathrm{C}$ ) and the serum was collected by centrifugation and stored at $-40^{\circ} \mathrm{C}$. The olfactory rosette and the brain were carefully isolated from the head. Tissues were fixed with $4 \%$ paraformaldehyde in $0.1 \mathrm{M}$ phosphate buffer (PB; pH7.2) for 30 min on ice. After rinsing with 0.1M PB containing $10 \%$ sucrose and $0.1 \mathrm{M}$ PB containing $20 \%$ sucrose, tissues were infiltrated with Tissue-Tek OCT compound (OCT; Miles Laboratories, Elkhart, Indiana, USA) in polyethylene capsules (Beem Capsule; Ernest F Fullam, Latham, New York, USA). Subsequently, the tissues were embedded in OCT and snap frozen in liquid nitrogen or dry ice acetone and stored at $-85^{\circ} \mathrm{C}$.

\section{Radioimmunoassay}

Serum thyroxine $\left(\mathrm{T}_{4}\right)$ and triiodothyronine $\left(\mathrm{T}_{3}\right)$ concentrations were measured by radioimmunoassay according to the modified method of Suzuki \& Suzuki (1981).

\section{In vitro autoradiography}

Serial frontal sections were cut at $10 \mu \mathrm{m}$ on a cryostat (Cryocut 1800; Reichert-Jung, Wien, Austria) and identified to belong to one of six brain regions (the olfactory epithelium, the olfactory bulb, the telencephalon, the front of the mid-brain, the rear of the mid-brain and the cerebellum including the medulla oblongata), as shown in Fig. 2. To locate these regions, sections adjacent to those for the receptor assay were stained with Delafield's hematoxylin 
and eosin (the olfactory epithelium) or cresyl violet. Brain regions were identified using the following:

1. olfactory epithelium - no description given;

2. olfactory bulb - presence of concentric laminae, consisting of (from the periphery inwards): the primary olfactory nerve fibers, the glomerular layer, the external cellular layer, the secondary olfactory fibers, the internal cellular layer;

3. telencephalon - presence of the area ventralis telencephali in the caudal third of the telencephalon;

4. front of mid-brain - presence of the hypothalamus and the ventriculus tertius;

5. rear of mid-brain - presence of the saccus vasculosus;

6. cerebellum including the medulla oblongata-presence of the stratum moleculare, the stratum ganglionare and the stratum granulare.

For terminology, we followed Northcutt \& Davis (1983) for the olfactory bulb and the telencephalon and Nieuwenhuys \& Pouwels (1983) for the mid-brain and the cerebellum. Frozen sections were mounted on a gelatin or poly-L-lysine-coated Superfrost slide glass (Matsunami, Osaka, Japan) and air dried overnight at $40^{\circ} \mathrm{C}$. After hydration in phosphatebuffered saline $\left(0.14 \mathrm{M} \mathrm{NaCl}, 2.68 \mathrm{mM} \mathrm{KCl}, 8.04 \mathrm{mM} \mathrm{Na}_{2} \mathrm{HPO}_{4} \cdot 12 \mathrm{H}_{2} \mathrm{O}, 1.47 \mathrm{mM} \mathrm{KH}_{2} \mathrm{PO}_{4}\right.$, $\mathrm{pH} 7.4$, PBS), the parts of non-specific binding sites were blocked with $5 \%$ bovine serum albumin in PBS for 20min, and incubated with $0.1 \mathrm{nM}{ }^{125} \mathrm{I}_{-} \mathrm{T}_{3}$ (New England Nuclear, Boston, Massachusetts, USA) (total binding) or $0.1 \mathrm{nM}^{125} \mathrm{I}_{-} \mathrm{T}_{3}+1000 \mathrm{nM} \mathrm{T}_{3}$ (non-specific binding) for $24 \mathrm{~h}$ at $40^{\circ} \mathrm{C}$. After incubation, sections were rinsed with PBS containing $0.1 \%$ Tween-20, PBS and distilled water. The sections were air dried and analysed with an X-ray imaging analyser (Fuji BAS2000; Fujifilm, Tokyo, Japan). For quantitative analysis, specific binding was calculated by subtracting the non-specific binding from the total binding.

\section{Saturation experiment}

In this experiment, the cerebellum including the medulla oblongata was used because the celebellum is a well-known target for thyroid hormone during neural development in mammals (Dussault \& Ruel1987). Sections were prepared as described above. After 
blocking, the sections were incubated with various concentrations $(0.01,0.1,0.25,0.5$, $1.0 \mathrm{nM}$ ) of ${ }^{125} \mathrm{I}_{-} \mathrm{T}_{3}$ (total binding) or ${ }^{125} \mathrm{I}_{-} \mathrm{T}_{3}+1000$-fold excess of unlabelled $\mathrm{T}_{3}$ (i.e. 0.1, $1.0,2.5,5.0,10 \mu \mathrm{M}$ ) (non-specific binding) for $24 \mathrm{~h}$ at $40^{\circ} \mathrm{C}$. Maximum binding capacity $(\mathrm{MBC})$ and equilibrium dissociation constant $\left(\mathrm{K}_{\mathrm{d}}\right)$ were calculated by Scatchard plot analysis.

\section{Statistics}

The data presented are expressed as means \pm SEM. One-way analysis of variance followed by Duncan's multiple range test were conducted on the data.

\section{Results}

Changes in serum $T_{4}$ and $T_{3}$ concentrations

Serum thyroid hormone levels were measured in masu salmon captured during the first sampling season (November 1991 to May 1992). Serum $T_{4}$ concentrations which remained low (1.45-5.82 ng/ml) from November to March, increased markedly from April to May and peaked $(15.63 \pm 1.36 \mathrm{ng} / \mathrm{ml})$ in May. Serum $\mathrm{T}_{3}$ concentrations were maintained at low levels $(0.12-0.47 \mathrm{ng} / \mathrm{ml})$ from November to March and increased gradually thereafter, reaching a

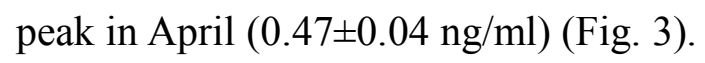

\section{Saturation and Scatchard plot analysis}

Tissue samples from the parr stage (November) were used in this analysis. Saturability of ${ }^{125} \mathrm{I}_{-} \mathrm{T}_{3}$ binding to the cerebellum including the medulla oblongata was determined using a range of ligand concentrations from 0.01 to $1.0 \mathrm{nM}$. Specific binding almost reached a plateau at $0.1 \mathrm{nM}(\mathrm{Fig} \cdot 4 \mathrm{~A})$. Scatchard plot analysis indicated a single class of binding sites. The $K_{d}$ value was $3.86 \times 10^{-10} \mathrm{M}$. The MBC value was $0.519 \mathrm{fmol} / \mathrm{cm}^{3}$ tissue (Fig. 4B).

\section{Detection of the $T_{3}$-specific binding sites in the olfactory epithelium and the brain}

Tissue samples from the parr stage (November) and full smolt stage (May) were used in this experiment. Specific binding of ${ }^{125} \mathrm{I}_{-} \mathrm{T}_{3}$ in six parts of the brain are as shown in Fig. 5. $\mathrm{T}_{3}$-specific binding in the olfactory epithelium was higher than in other parts of the brain at both the parr and full-smolt stages. Relatively little binding in the olfactory bulb and the 
telencephalon was observed at these stages. The binding in the cerebellum was highest in the brain of fish at the parr stage. However, the binding in the mid-brain was higher than in other brain regions of fish at the full-smolt stage.

\section{Autoradiography}

${ }^{125} \mathrm{I}_{-} \mathrm{T}_{3}$-specific binding in the olfactory epithelium (the olfactory rosette) was mainly observed by radioactive signals in the olfactory epithelial layer. Binding was observed by low radioactive signals in the connective tissue and the olfactory nerve (Fig. 6A, B). Total binding was observed by high radioactive signals in the olfactory epithelium (Fig. 6C), while non-specific binding was observed by very low radioactivity (Fig. 6D).

\section{Changes in $T_{3}$-specific binding value in the olfactory epithelium}

Tissue samples from the parr stage (November), pre-smolt stage (April), and full-smolt stage (May) were used in this experiment. ${ }^{125} \mathrm{I}_{-} \mathrm{T}_{3}$-specific binding in the olfactory epithelium indicated low levels $\left(8.0-9.0 \mathrm{dpm} / \mathrm{mm}^{2}\right)$ at the parr and pre-smolt stage, and increased markedly at the full-smolt stage (16.5-17.2 dpm/mm²) in May 1992 and 1993 (Fig. 7).

\section{Discussion}

In the present study, the patterns in serum $T_{4}$ and $T_{3}$ fluctuations in wild masu salmon were consistent with those in hatchery-reared fish (Ura et al. 1994). However, the maximum value of serum $T_{4}$ concentrations in wild masu salmon at the full-smolt stage was higher (15.6 $\mathrm{ng} / \mathrm{ml}$ ) than that in hatchery reared fish at the same stage (about $7.0 \mathrm{ng} / \mathrm{ml}$; Ura et al. 1993; H. Kudo, unpublished data).

Saturation and Scatchard plot analysis of ${ }^{125} \mathrm{I}_{-} \mathrm{T}_{3}$-specific binding value to the cerebellum indicated that only one binding site was present and this binding site had a high affinity. The $K_{d}$ value in the present results was similar to that in the liver of brown trout, Salmo trutta L. (3.61 $\times 10^{-10} \mathrm{M}$; Lebel \& Leloup1989). The MBC could not be compared with previous studies because the unit of previous studies (fmol/mg DNA or fmol/mg protein) was different from the unit in the present study $\left(\mathrm{fmol} / \mathrm{cm}^{3}\right.$ tissue). Further work by the present method is needed to examine changes in $K_{d}$ and MBC values during smolting in the CNS. In previous studies, the thyroid hormone receptor was detected by in vitro binding assay with the 
homogenate of tissues (Bernal \& Pekonen1984; Ruel, Faure \& Dussault1985; Bres \& Eales1988). In these studies, $T_{3}$ binding sites were detected in cell nuclei from brain homogenate, but this method requires many samples. Therefore, a detailed analysis of intricate organs, e.g. CNS, could not be performed. The in vivo autoradiography of the thyroid hormone receptor was examined using tissue sections and ${ }^{3} \mathrm{H}$-sensitive film after injection of ${ }^{125} \mathrm{I}_{-} \mathrm{T}_{3}$ in rat brains (Dratman, Crutchfield, Futaesaku, Goldberger \& Murray1987). By observing the developed ${ }^{3} \mathrm{H}$-sensitive film of the brain, localization of $\mathrm{T}_{3}$ binding was clarified. However this method could only semi-quantify the $\mathrm{T}_{3}$-specific binding value because radioactivity was measured by counting the density of the silver grains in the autoradiogram. In addition, this method could not be used to compare different stages, such as the parr and smolt stages in the present study, owing to the short half-life of ${ }^{125} \mathrm{I}_{-} \mathrm{T}_{3}$. With the present technique, a light fixation by $4 \%$ paraformaldehyde can prevent receptor binding from decreasing and the sample can be stored at $-85^{\circ} \mathrm{C}$ until use. On the other hand, the receptor binding of the intact sample rapidly decreased during storage at $-85^{\circ} \mathrm{C}(\mathrm{H}$. Kudo, unpublished data). The present technique was therefore, very suitable to examine changes in $\mathrm{T}_{3}$-specific binding values during smolting. Moreover, the quantification and localization of the thyroid hormone receptor could be actualized using the same sample by use of an X-ray imaging analyzer. Adjacent sections could be used for additional analyses, i.e.

histochemistry, immunohistochemistry and autoradiography, of other ligands. Thus, the present in vitro autoradiography technique using frozen sections is a powerful tool in detecting the thyroid hormone receptors in all regions of a single brain, although the localization of $\mathrm{T}_{3}$ binding sites could not be detected at the cytological level.

$\mathrm{T}_{3}$-specific binding was detected in the olfactory epithelium and all regions of the brain except the olfactory bulb, indicating the presence of thyroid hormone receptors in the CNS of masu salmon. The present study is the first report to demonstrate the presence of $\mathrm{T}_{3}$-specific binding in detailed regions of the brain in teleosts. The results indicate that the highest binding was recorded in the cerebellum of fish at the parr stage. The cerebellum of teleost is known to contain many motor neurons (the cerebellomotorius system) (Nieuwenhuys \& Pouwels 1983). Further, nuclear $\mathrm{T}_{3}$ receptors in the brain have been found to increase during neural development in higher vertebrates (Chandrasekhar, Moskovkin \& Mitskevich 1979; Dussault \& Ruel1987; Ferreiro, Bernal, Morreale de Escobar \& Potter1988), suggesting 
that the thyroid hormone regulates synaptic formation and arborization of axons and dendrites. Thus, the present results suggest that the cerebellum at the parr stage may play a role in similar processes. The motor function of fish at the parr stage might also be developing. On the other hand, $\mathrm{T}_{3}$-specific binding in the mid-brain, which includes the hypothalamus, the thalamus and the optic tectum, was higher than in other brain regions in samples of the full-smolt stage. Therefore, the thyroid hormone receptors of the mid-brain at the full-smolt stage may be related to smolt-specific functions, such as downstream behaviour, osmoregulation and visual function. In this study, $\mathrm{T}_{3}$-specific binding values in the olfactory bulb and the telencephalon were very low. However, a high level of thyroid hormone binding and expression of c-erb A (thyroid hormone receptor encoding gene) has been reported in the mitral cell layer of the rat olfactory bulb (Ruel et al. 1985; Mellström, Naranjo, Santos, Gonzalez \& Bernal 1991). The low level of $\mathrm{T}_{3}$-specific binding in the olfactory bulb might be caused by the fact that the number of cells is few.

The $\mathrm{T}_{3}$-specific binding value in the olfactory epithelium was higher than in any other region of the brain at both the parr and full-smolt stages. In this tissue in mammals, a constant turnover has been demonstrated from basal cells into olfactory receptor cells with axons projecting into the olfactory bulb (Monti Graziadei \& Graziadei 1979). Hence, the high $\mathrm{T}_{3}$-specific binding value in the olfactory epithelium may imply that thyroid hormone receptors in the nuclei of basal cells or olfactory receptor cells may be involved in synaptic formation during turnover, similar to the developing neuron. This interpretation may explain why the $\mathrm{T}_{3}$-specific binding value in the olfactory epithelium was higher than that in the brain.

$\mathrm{TheT}_{3}$-specific binding value in the olfactory epithelium clearly increased at the full-smolt stage. In hatchery-reared masu salmon, however, it was maintained at low levels (under $8 \mathrm{dpm} / \mathrm{mm}^{2}$ ) even at the full-smolt stage (H. Kudo, unpublished data). This result may relate to the fact that the serum $\mathrm{T}_{4}$ level in wild fish was higher than that in hatchery-reared fish, which may be a characteristic of wild fish. Further work is needed to examine the details of the difference between wild and hatchery-reared fish under various physiological factors. For instance, downstream migration is associated with various environmental changes (e.g. water, food and physical factors). The increase in the $\mathrm{T}_{3}$-specific binding value in the olfactory epithelium may be caused by the intense turnover of 
the olfactory epithelial cells. Changes in the type of skin, teeth and pelvic fin have also been related to environmental changes, e.g. smolting in coho salmon (Gorbman, Dickhoff, Mighell, Prentice \& Waknitz 1982). Alternatively, the olfactory epithelium may be exposed to different types of odorants in the sea as compared to the river, thus bringing about a change in $\mathrm{T}_{3}$-specific binding.

More recently, we identified an olfactory-specific protein of $24 \mathrm{kDa}(\mathrm{N} 24)$ in kokanee salmon, Oncorhynchus nerka (Walbaum) (Shimizu, Kudo, Ueda, Hara, Shimazaki \& Yamauchi 1993). The immunoreactivity of N24 in olfactory tissues was stronger at the Parr stage than at the full-smolt stage using Western blot analysis. This result indicates that N24 varies in inverse proportion to thyroid hormone during smolting of wild masu salmon. It is assumed that the thyroid hormone may inhibit the expression of N24 in the olfactory receptor cell. Thus, thyroid hormone receptors and N24 may prove to be useful molecular markers for investigating the olfactory functions during smolting, including imprinting and migration, in salmonids.

In conclusion, the analysis of $\mathrm{T}_{3}$-specific binding by the present technique enabled detection of thyroid hormone receptors in various regions of the CNS, and indicated the high binding capability of thyroid hormone receptors in the olfactory epithelium. The present results suggest that the thyroid hormone plays an important role in the functional changes in the brain and the olfactory epithelium during smolting. Further work is required to investigate whether changes in the expression of thyroid hormone receptor encoding gene or protein occurs along with changes in $\mathrm{T}_{3}$-specific binding capability during smolting. Studies are now under way regarding the cDNA cloning of thyroid hormone receptors and N24 at our laboratory. These studies will provide information on the role of the thyroid hormone during smolting in the CNS including the olfactory system of salmonids.

\section{Acknowledgments}

We thank Dr Kiyoshi Soyano, Nagasaki University and Mr Takashi Todo, Hokkaido Univeristy, for technical advice. We alsot hank Mr Mark Lokman, University of Otago, New Zealand, for critically reading the manuscript. This study was supported in part by a Grant-in-Aid for Scientific Research from the Ministry of Education, Science and Culture, Japan. 


\section{References}

Bernal J. and Pekonen F (1984) Ontogenesis of the nuclear 3,5,3'-triiodothyronine receptor in the human fetal brain. Endocrinology 114, 677-679.

Bres O. and Eales J. G. (1988) High-affinity, limited-capacity triiodothyronine-binding sites in nuclei from various tissues of the rainbow trout (Salmo gairdneri ). General and Comparative Endocrinology 69, 71-79.

Chandrasekhar K., Moskovkin G. N. and Mitskevich M. S. (1979) Effect of methylthiouracil and triiodothyronine on development of the central nervous system in chicken embryos. General and Comparative Endocrinology 37, 6-14.

Dickhoff W. W., Folmar L. C., Mighell J. L. and Mahnken C. V. W. (1982) Plasma thyroid hormones during smoltification of yearling and underyearling coho salmon and yearling chinook salmon and steelhead trout. Aquaculture 28, 39-48.

Dratman M. B., Crutchfield F. L., Futaesaku Y., Goldberger M. E. and Murray M. (1987) [ ${ }^{125}$ I] Triiodothyronine in the rat brain: evidence for neural localization and axonal transport derived from thaw-mount film autoradiography. The Journal of Comparative Neurology $\mathbf{2 6 0}$, $392-408$.

Dussault J. H. and Ruel J. (1987) Thyroid hormones and brain development. Annual Review of Physiology 49, 321-334.

Ferreiro B., Bernal J., Morreale de Escobar G. and Potter B. J. (1988) Preferential saturation of brain 3,5,3'-triiodothyronine receptor during development in fetal lambs. Endocrinology 122, 438-443.

Folmar L. C. and Dickhoff W. W. (1980) The parr-smolt transformation (smoltification) and seawater adaptation in salmonids. A review of selected literature. Aquaculture 21, 1-37.

Gorbman A., Dickhoff W. W., Mighell J. L., Prentice E. F. and Waknitz F. W. (1982)

Morphological indices of developmental progress in the parr-smolt coho salmon,

Oncorhynchus kisutch. Aquaculture 28, 1-19.

Hoar W. S. (1976) Smolt transformation: evolution, behavior, and physiology. Journal of the Fisheries Research Board of Canada 33, 1233-1252.

Hoar W. S. (1988) The physiology of smolting salmonids. In: Fish Physiology. (ed. by Hoar W. S. and Randall D. J.), Academic Press New York, Vol. XIB, pp275-343.

Lebel J. M. and Leloup J. (1989) Triiodothyronine binding to putative solubilized nuclear 
thyroid hormone receptor in liver and gill of the brown trout (Salmo trutta) and the European eel (Anguilla anguilla ). General and Comparative Endocrinology 75, 301-309.

Mellström B., Naranjo J. R., Santos A., Gonzalez A.M. and Bernal J. (1991) Independent expression of the a and b c-erb A gene in developing rat brain. Molecular Endocrinology 5, 1339-1350.

Monti Graziadei G. A. and Graziadei P. P. C. (1979) Functional morphology of the olfactory sensory neuron. In: Neural Growth and Differentiation. (ed. by Meisami E. and Brazier M. A. B.), IBRO, Vol.5 5, pp373-396

Nieuwenhuys R. and Pouwels E. (1983) The brain stem of actinopterygian fishes. In: Fish Neurobiology. (ed. by Davis R. E. and Northcutt R. G.), Univ. of Michigan Press Ann Arbor, Vol. I, pp25-87

Northcutt R. G. and Davis R. E. (1983) Telencephalic organization in ray-finned fishes. In: Fish Neurobiology. (ed. by Davis R. E. and Northcutt R. G.), Univ. of Michigan Press Ann Arbor, Vol. II, pp203-235

Ruel J., Faure R. and Dussault J. H. (1985) Regional distribution of nuclear T3 receptors in rat brain and evidence for preferential localization in neurons. Journal of Endocrinological Investigation 8, 343-348.

Scholz A. T., White R. J., Muzi M. and Smith T. (1985) Uptake of radiolabelled triiodothyronine in the brain of steelhead trout (Salmo gairdneri ) during parr-smolt transformation: Implication for the mechanism of thyroid activation of olfactory imprinting. Aquaculture 45, 199-214.

Shimizu M., Kudo H., Ueda H., Hara A., Shimazaki K. and Yamauchi K. (1993) Identification and immunological properties of an olfactory system-specific protein in kokanee salmon (Oncorhynchus nerka ). Zoological Science 10, 287-294.

Suzuki M. and Suzuki M. (1981) Changes in thyroidal and plasma iodine compounds during and after metamorphosis of the bullfrog, Rana catesbeiana. General and Comparative Endocrinology 45, 75-81.

Ura K., Hara A. and Yamauchi K. (1993) Serum thyroid hormone, guanine and protein profiles during smoltification and after thyroxine treatment in the masu salmon, Oncorhynchus masou . Comparative Biochemistry and Physiology 107A, 607-612.

Yamauchi K., Koide N., Adachi S. and Nagahama Y. (1984) Changes in seawater adaptability 
and blood thyroxine concentrations during smoltification of the masu salmon, Oncorhynchus masou, and the amago salmon, Oncorhynchus rhodurus. Aquaculture 42, 247-256.

Young G., Björnsson B. T., Prunet P., Lin R. J. and Bern H. A. (1989) Smoltification and seawater adaptation in coho salmon (Oncorhynchus kisutch ): Plasma prolactin, growth hormone, thyroid hormones, and cortisol. General and Comparative Endocrinology 74, $335-345$. 


\section{Figure Legends}

Figure 1. Changes in fork length (FL; - ), body weight $(\mathrm{BW} ; \bigcirc)$ of wild masu salmon, and water temperature ( $\square$ ) in the Shakotan River during smolting from November 1991 to May1992. Values represent the means $\pm \operatorname{SEM}(\mathrm{n}=10-15)$.

Figure 2. Schematic illustration of a lateral view of the masu salmon brain and olfactory system showing sites of frozen sections (dashed lines). OE, olfatory epithelium; OB, olfactory bulb; $\mathrm{T}$, telencephalon; $\mathrm{MB}_{1}$, front of mid-brain; $\mathrm{MB}_{2}$, rear of mid-brain; $\mathrm{C}$, cerebellum including the medulla oblongata.

Figure 3. Changes in serum thyroxine $\left(\mathrm{T}_{4} ; \bigcirc\right)$ and triiodothyronine $\left(\mathrm{T}_{3} ; \bullet\right)$ levels of wild masu salmon during smolting in1991-1992. Values represent the means $\pm \operatorname{SEM}(n=8-10)$.

Figure 4. Saturation of ${ }^{125} \mathrm{I}_{-} \mathrm{T}_{3}$ binding in the cerebellum. (A) The cerebellum section was incubated for $24 \mathrm{~h}$ at $40^{\circ} \mathrm{C}$ with a range of ${ }^{125} \mathrm{I}_{-} \mathrm{T}_{3}$ concentrations from 0.01 to $0.5 \mathrm{nM}$. Scatchard plot of the specific binding in (A). $K_{d}=3.86 \times 10^{-10} \mathrm{M}, \mathrm{MBC}=0.519 \mathrm{fmol} / \mathrm{cm}^{3}$ tissue.

Figure 5. Compadson of ${ }^{125} \mathrm{I}_{-} \mathrm{T}_{3}$ specific binding in various parts of the olfactory system and the brain in wild masu salmon parr (A) and full-smolts (B). Values represent the means \pm SEM $(n=4-5) . \quad$ ND, non-detectable.

Figure 6. Autoradiograms of ${ }^{125} \mathrm{I}_{-} \mathrm{T}_{3}$ binding in the olfactory rosette of masu salmon. total binding; (B) counter stained with hematoxylin and eosin, Small arrowheads indicate the olfactory epithelium. Large arrowheads indicate the olfactory nerve. C, total binding; D, non-specific binding. Bar $1.0 \mathrm{~mm}$.

Figure 7. Changes in $\mathrm{T}_{3}$-specific binding in the olfactory epithelium of wild masu salmon during smolting. Values represent the means $\pm \operatorname{SEM}$ (n; sections $=13-31$ ). * Significantly different from parr and pre-smolts $(P<0.01)$. 


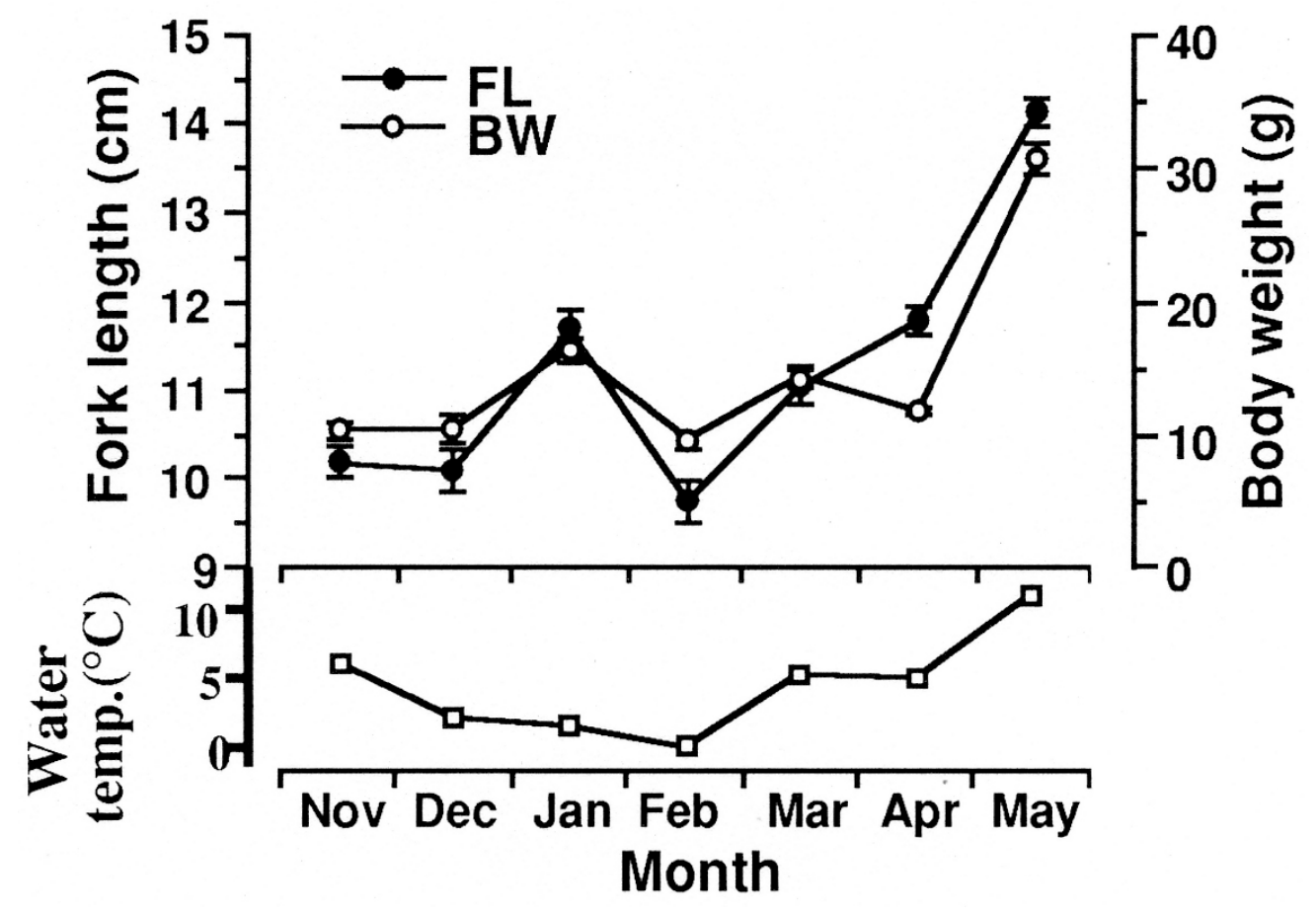

Kudo et al.

Figure 1 


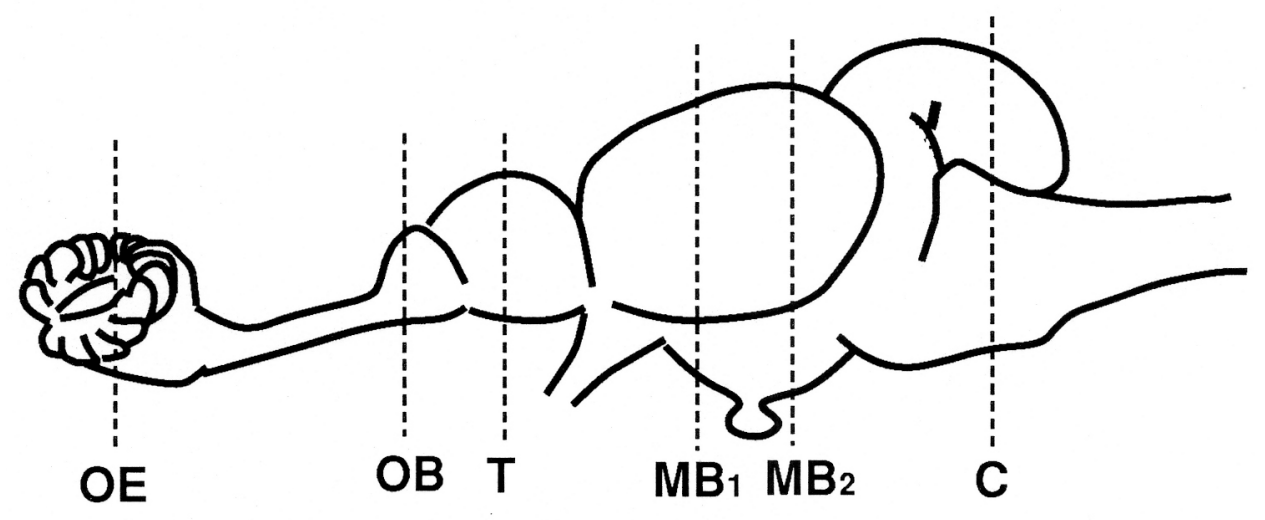

Kudo et al.

Figure 2 


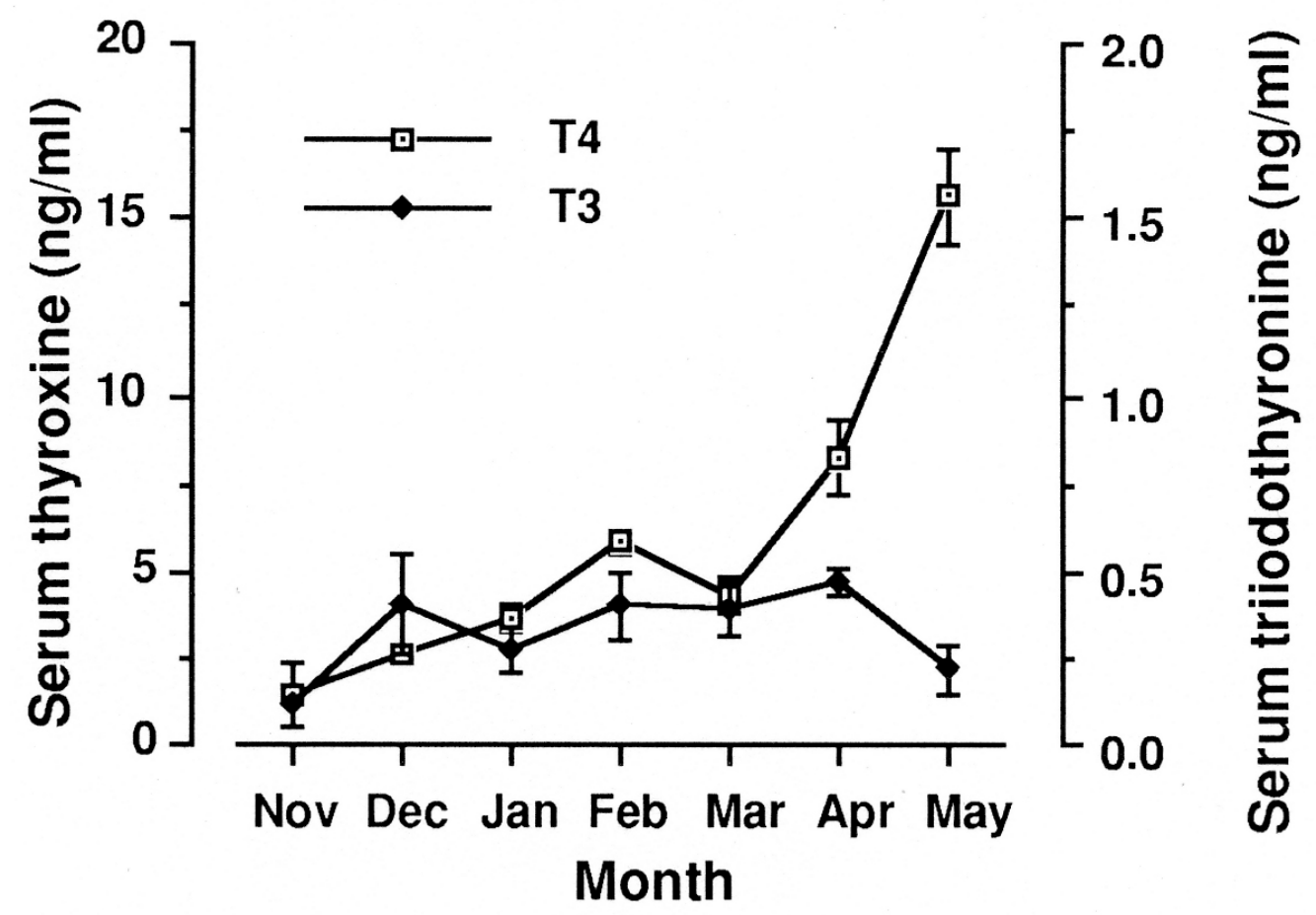

Kudo et al.

Figure 3 


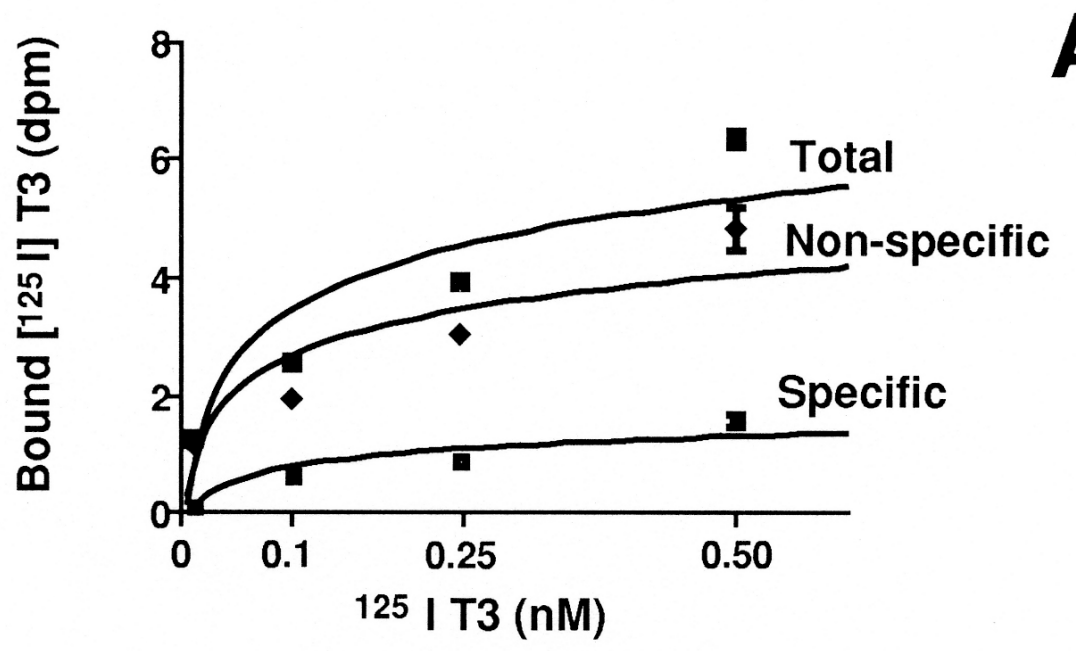

A

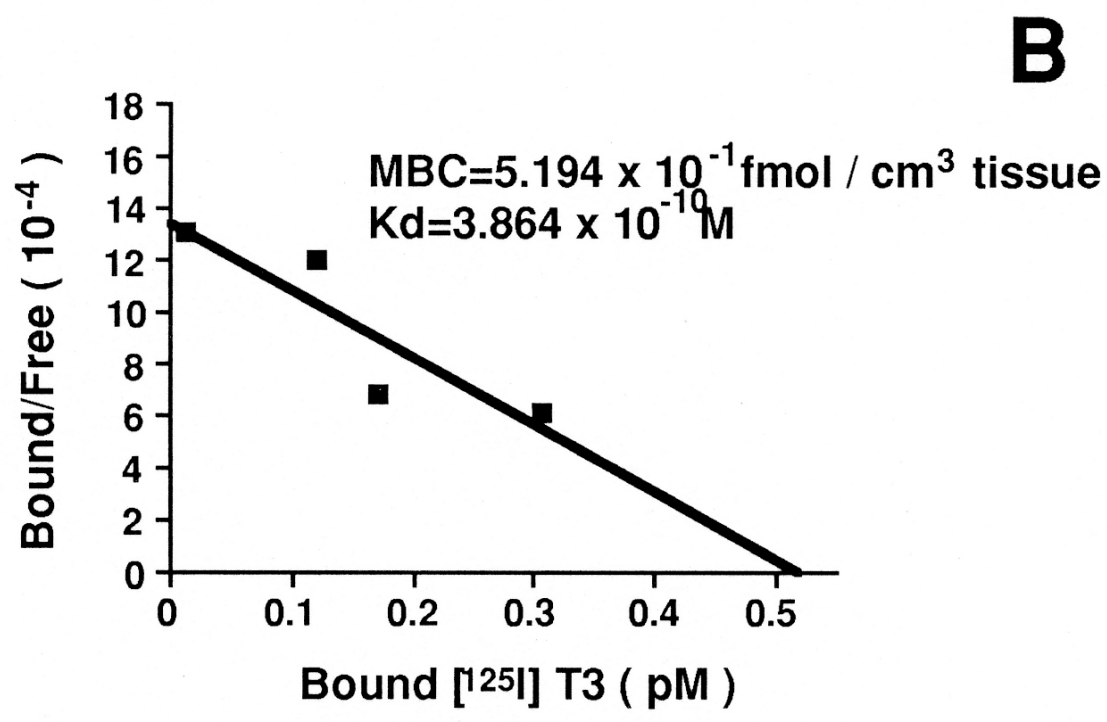

Kudo et al.

Figure 4 

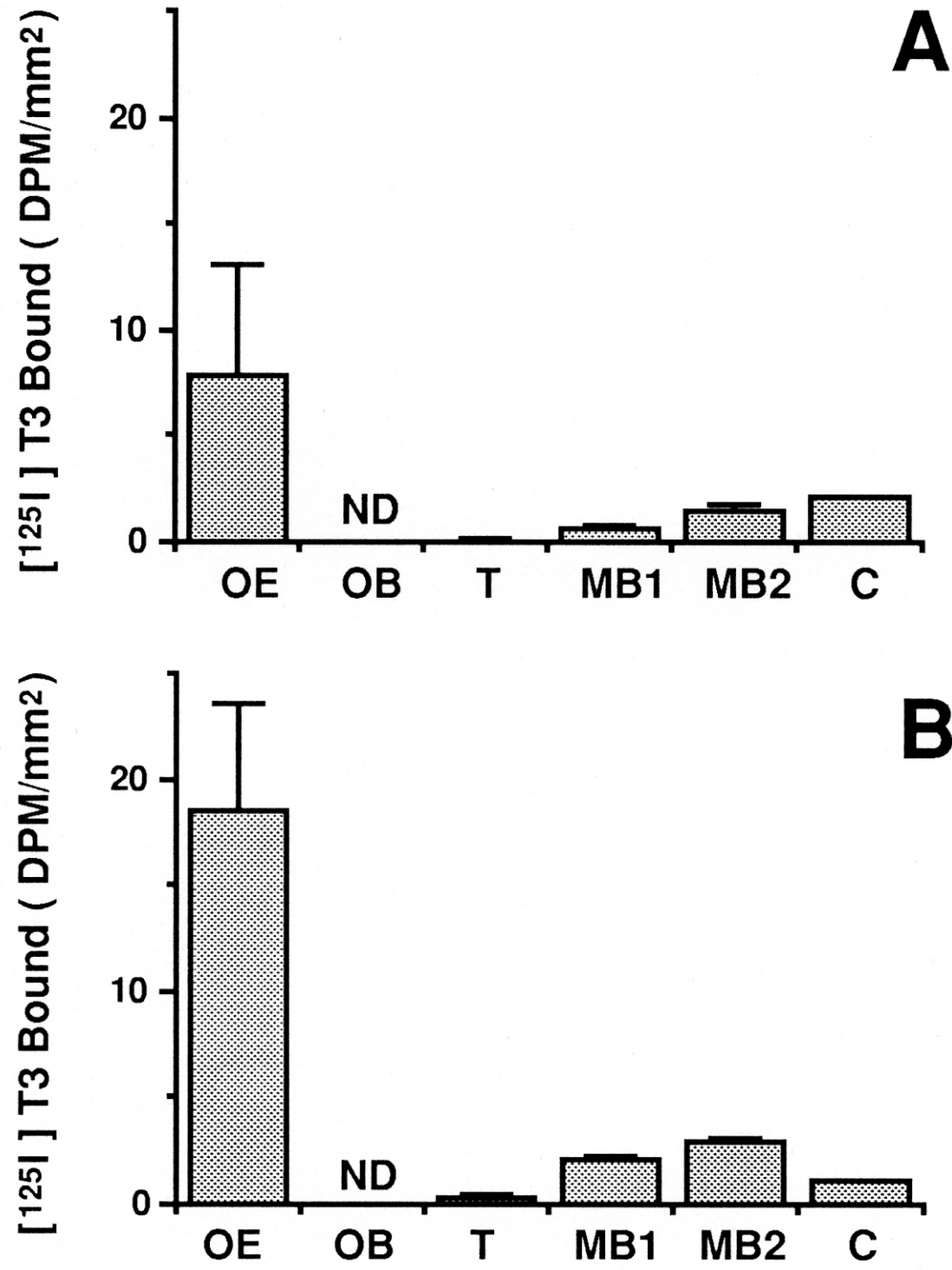

Kudo et al.

Figure 5 

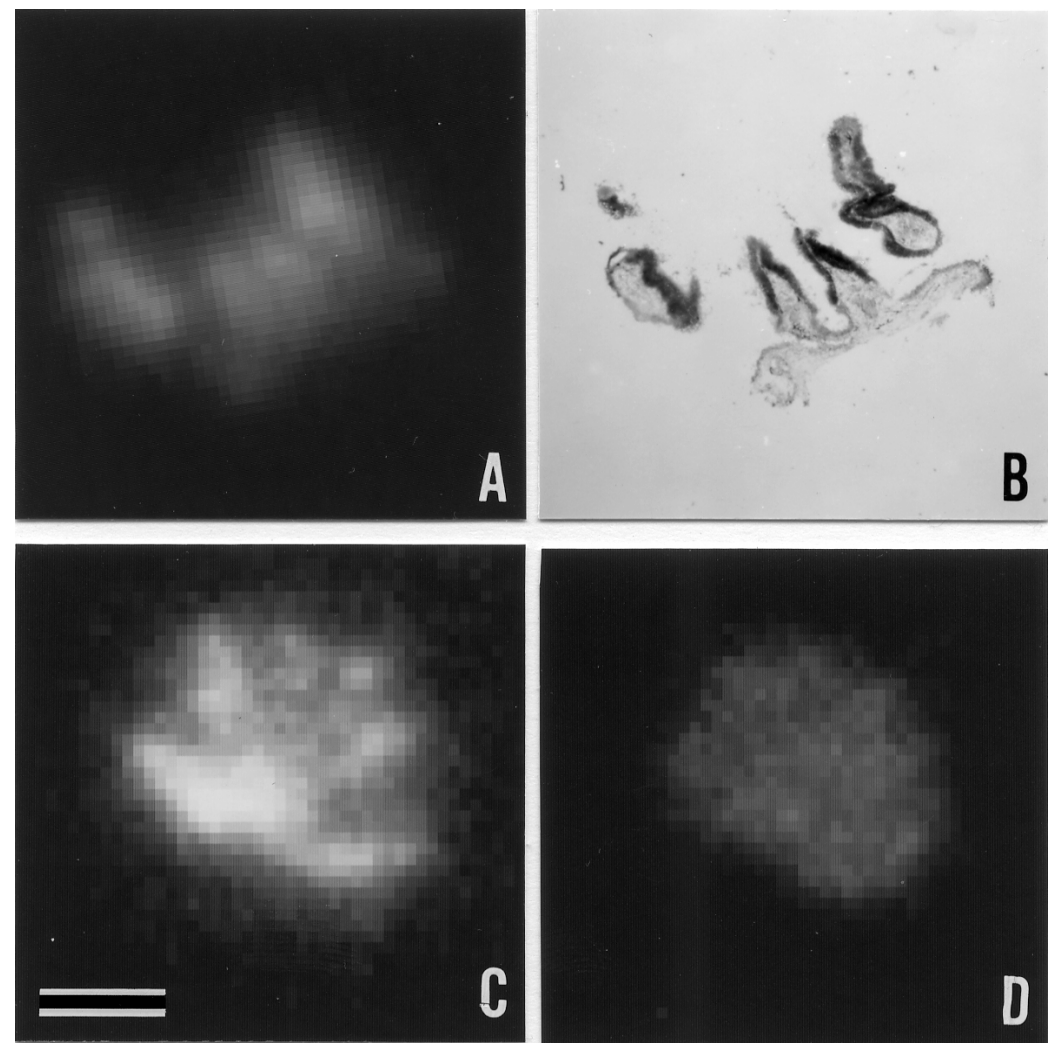

Kudo et al.

Figure 6 


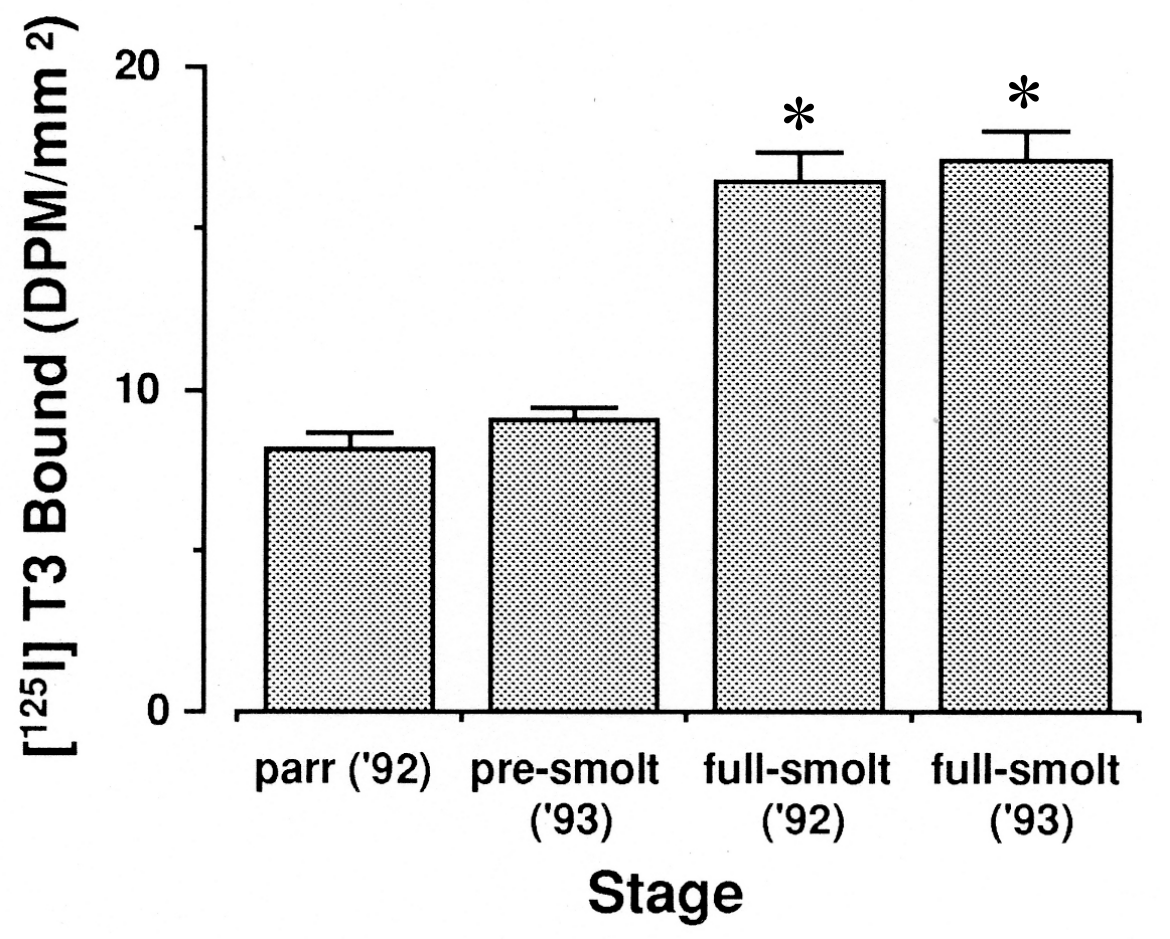

Kudo et al.

Figure 7 